\title{
CURRENT APPLICATION OF EXOSOMES IN MEDICINE
}

\author{
Rut Bryl ${ }^{1}$, Blanka Borowiec ${ }^{1}$, Rafael Shinoske Siroma², Nelson Pinto², Marcelo A. Melo², Jamil A. \\ Shibli², Marta Dyszkiewicz-Konwińska ${ }^{3,4}$
}

\begin{abstract}
Exosomes belong to structures called extracellular vesicles (EVs). These spherical units, secreted by most eukaryotic cells, attracted significant interest among researchers in recent years. Exosomes undergo secretion from almost all types of mammalian cells, including dendritic cells, B cells, epithelial cells, mastocytes, reticulocytes, platelets, $\mathrm{T}$ cells, mesenchymal stem cells, adipocytes, bone marrow-derived stem cells, embryonic stem cells, fibroblasts, cardiac myocytes, endothelial cells, oligodendrocytes, astrocytes, microglia, neurons, neural stem cells, hepatocytes, lung spheroid cells, as well as tumor cells. Exosomes have several features that enable many methods of their isolation from biological material. Furthermore, physicochemical properties such as size, mass, density, or the ability to interact with specific proteins allowed for the development and advance of several effective methods. Work on exosomes' recovery and purity made it possible to most effectively determine their isolation methods' efficiency and accuracy. A common ground for the researchers' interest in exosomal analyses is the role of exosomes as carriers of disease biomarkers. It has been suggested that exosomes can be used in vaccine development and other immunological-related purposes, as one of their characteristics is the ability to present antigens. Moreover, exosomes have a long half-life. As the human body does not perceive them as foreign bodies, they can penetrate cell membranes and target specific cells, making them even better candidates for the applications mentioned above. Therefore, the following review deals with the nature of exosomes, as well as various methods of their isolation and use in medicine.
\end{abstract}

Running title: Current application of exosomes in medicine

Keywords: exosomes, application of exosomes, isolation of exosomes

\footnotetext{
'Department of Histology and Embryology, Poznań University of Medical Sciences, Poznań, Poland

${ }^{2}$ Department of Periodontology and Oral Implantology, Dental Research Division, Guarulhos University, Guarulhos, SP, Brazil

${ }^{3}$ Department of Biomaterials and Experimental Dentistry, Poznań University of Medical Sciences, Poznań, Poland

${ }^{4}$ Department of Anatomy, Poznań University of Medical Sciences, Poznań, Poland

* Correspondence: m.dyszkiewicz@ump.edu.pl

Full list of author information is available at the end of article
} 


\section{Introduction}

Exosomes belong to a group of structures called extracellular vesicles (EVs). These spherical units, secreted by most eukaryotic cells, have attracted increasing interest among researchers in recent years. The first mentions of exosomes appeared in 1983. Two publications on exosomes were then published in the journals Cell and Journal of Cell Biology just a week apart, though they had not yet been named at the time. In this study, it was then confirmed that the transferrin receptors in reticulocytes are associated with small vesicles, which are then secreted from the maturing reticulocytes into the extracellular space. The name "exosome" only was clarified a few years later, by Rose Johnstone from the Department of Biochemistry at the Medical Faculty of McGill University in Canada [1]. Fourteen years later, a structure called the exosome complex or often wrongly - the exosome was also discovered. These two concepts should not be confused as the exosome complex (or PM / Scl complex) is a nucleolar macromolecular complex with ribonuclease properties, playing a role in mRNA degradation and ribosomal RNA processing [2]. Exosome complexes are found in both eukaryotic cells and archaea. In bacteria, on the other hand, there is a simpler complex with similar functions, called the degradosome $[3,4]$. It is therefore incorrect to use the names "exosome" and "exosome complex" interchangeably. The initial confusion around exosomes contributed to a sharp expansion of interest among researchers, which continues to the present day. In recent years, exosomes have gained enormous popularity, although about 30 years ago no one heard of them. We can be sure that all their known features will be used to improve various areas of science and medicine. The following work discusses the nature of exosomes, i.e. their characterization, source of origin, mechanisms of biogenesis, secretion and uptake and their variable content (cargo). We also present their most popular isolation methods, such as sizebased isolation, immunoaffinity, density-based isolation and co-precipitation. Finally, we discuss some of the uses of exosomes in human therapies based on their best-known features.

\section{The source of exosomes}

Exosomes undergo secretion from almost all types of mammalian cells, including dendritic cells, B cells, epithelial cells, mastocytes, reticulocytes, platelets, T cells [5], mesenchymal stem cells [6], adipocytes [7], bone marrow-derived stem cells and embryonic stem cells [8], fibroblasts, cardiac myocytes and endothelial cells $[9,10]$, oligodendrocytes, astrocytes, microglia, neurons [11,12], neural stem cells [13], hepatocytes [14], lung spheroid cells [15] as well as tumour cells [16]. Their presence in various body fluids such as plasma, saliva, urine, amniotic fluid [17], serum [18], cerebrospinal fluid [19], lymph [20], sperm [21], breast milk [22], bile [23], bronchoalveolar lavage fluid [24], synovial fluid [25], gastric juice [26], tears [27] and malignant effusions [28] has also been demonstrated.

For the first time, exosomes were described as vesicles exhibiting 5'-nucleotidase activity released by neoplastic cell lines [29]. Subsequently, their presence was observed in studies of reticulocyte maturation process. It was shown that they localize in multivesicular endosomes and contain transferrin receptors. Initially, exosome secretion was proposed as a means of elimination of cellular contents, such as unnecessary proteins [30,31]. However, in the late 90 s, their role in intercellular communication, with implications in immunological response was proved [32]. The 2007 study of Valadi et al. reported that exosomes contain mRNAs and miRNAs, which can participate in cell-cell communication and exert functions in recipient cells [33] These results evoked increasing interest in the biology and application of these extracellular vesicles.

\section{Exosome biogenesis, release and uptake}

The biogenesis of exosomes involves double invagination of the plasma membrane. In the first step, a cup-shaped structure is formed, comprised of cell-surface proteins, as well as soluble proteins associated with the extracellular environment. This, in turn, leads to generation of an early endosome. Early endosome can undergo maturation into late endosome to give rise to multivesicular body (MVB). MVBs formation occurs through inward invagination of endosomal limiting membrane, which produces intraluminal vesicles (ILVs) in the lumen of these organelles. Mature multivesicular bodies can either be degraded via fusion with lysosomes or autophagosomes. Furthermore, if fused with plasma membrane, contained ILVs can be released into the extracellular space to generate a subtype of EVs termed 'exosomes' [5,34-36]. It is worth mentioning that, unlike other intracellular budding events, endosome ILVs bud away from the cytosol, which means that their membrane orientation is exactly the same as that of the cell surface - extracellular domains of transmembrane proteins are exposed to the environment, while cytosolic components are enclosed [36]. Numerous molecules have been attributed to the exosome biogenesis and/or release, most notably using ESCRT (The endosomal sorting complex required for transport), TSG101 (tumour susceptibility gene 101 protein), ALIX (apoptosis-linked gene 2-interacting protein X), VPS4 (vacuolar protein sorting-associated protein 4), nSMAse-2 (neutral sphingomyelinase), ceramide, syntenin-1, syndecan-1, Rab GTPases, SNAREs (soluble N-ethylmaleimide-sensitive fusion attachment protein receptor), and tetraspanins $[37,38]$. In addition, it was postulated that $\mathrm{pH} /$ acidification may play a role in determining the level of exosome production [39]. 
The mechanisms underlying exosome uptake are still largely unknown and lack consensus, with their uptake mechanisms, possibly through micropinocytosis, macropinocytosis or in a receptor-dependent manner, remain to be elucidated. Exosome internalization can rely on clathrin-mediated endocytosis (CME) or occur in a clathrin-independent process [40]. Important classes of proteins involved in exosome uptake include: tetraspanins, integrins, lectins, proteoglycans and immunoglobulins [41]. As illustrated by growing evidence, it is also uncertain whether the process is target (acceptor cell)-specific or rather random. For instance, in a study by Fitzner et al., it was demonstrated that, when Olineu cell line-derived exosomes containing PLP were applied to neuronal cells in primary cortical culture, microglia, oligodendrocytes and astrocytes, they were preferentially internalized by microglia [42]. However, human carcinoma cell lines, precisely A549 (lung), HCT116 and COLO205 (colon) take up donor-derived exosomes non-selectively [43]. In addition, it should be noted that information from exosomes may be passed to the cell surface, without the necessity of cargo delivery, as in some cases of EVs expressing major histocompatibility complex (MHC)-peptide complexes [36].

\section{Exosome content}

Exosomes are a heterogenous family of lipid-bilayer enclosed extracellular vesicles, with a typical density on sucrose gradients ranging from 1.07 to $1.22 \mathrm{mg} / \mathrm{L}$ [44-46] and 30-150 $\mathrm{nm}$ in size [47-49]. Their biological content consists of various proteins, lipids and nucleic acids. According to ExoCarta (www.exocarta.org), a database depositing information on exosomal proteins, RNAs and lipids from various organisms and cell types, 41,860 proteins, $>7,540$ RNA and 1,116 lipids have been identified until now [50]. The content of these EVs is highly dependent on their cellular origin, status quo of the cell and the microenvironment. For instance, the proteomic analysis of breast cancer cells-derived exosomes revealed that exosomal protein content reflects epithelial- or mesenchymal-like phenotype of the cell-of-origin [51]. Exosomes from antigen presenting cells (APCs) carry MHC II molecules, which enable activation of specific $\mathrm{T}$ cells [52]. In turn, microglia-derived exosomes express aminopeptidase CD13, involved in neuropeptide catabolism and the lactate transporter MCT - 1 [53]. It was also observed that oncogenic alteration EGFRvIII (epidermal growth factor receptor variant III) in glioblastoma cells influences the cargo of EVs leading to enrichment in proinvasive proteins [54]. Despite their heterogeneity, a subset of molecules can be commonly found in majority of exosomes. These include proteins involved in MVB biogenesis (ALIX, TSG110, VPS, clathrin) and membrane fusion and transport (annexins, Rab proteins, ARF
GTPases), as well as cytoskeletal components (actin, myosin, tubulin, vimentin), tetraspanins (CD9, CD63, CD81, CD82), heat shock proteins (HSP90, HSP70), adhesion proteins (lactadherin, integrins, ICAM-1), metabolic enzymes (GAPDH, PKM, glucose-6-phosphate isomerase) and signal transduction proteins (Ras-related protein, flotillin, syntenin-1) $[5,35,55,56]$.

Another class of molecules considered as essential components of exosomes are lipids. Studies demonstrated that specific lipids, namely cholesterol (CHOL), sphingomyelin (SM), glycosphingolipids, ceramides and phosphatidylserine (PS) are two to four times enriched in exosomes compared to their parent cells, while a similar mole percent in cells and exosomes was observed for phosphatidylethanolamine (PE), with a lower mole percent of phosphatidylcholine (PC) and phosphatidylinositol (PI) $[57,58]$. Quantitative lipidomic data for PC-3 cells-derived exosomes suggests an asymmetric distribution of lipids in the two membrane leaflets - with very-long-chain sphingolipids predominant in the outer and PS in the inner leaflet [58]. In addition, bioactive lipids, including prostaglandins and leukotriens, as well as lipolytic enzymes (phospholipases), were identified in exosomes [59]. For example, prostaglandin E2 (PGE2) encapsulated in tumor-derived exosomes is involved in MDSC (myeloid-derived suppressor cells) - mediated promotion of tumor progression [60].

Aside from proteins and lipids, it has been reported that exosomes comprise a variety of RNA species, i.e. mRNA, miRNA, IncRNA, circRNA, tRNA, rRNA and other non-coding RNAs, as well as exosomal DNA (exoDNA) [61-64]. RNA-seq analysis of human plasma-derived exosomal RNA has revealed that miRNAs were the most abundant, making up over $42.32 \%$ of all raw reads and $76.20 \%$ of all mappable reads, while other species detected included ribosomal RNA (9.16\% of all mappable counts), long non-coding RNA (3.36\%), piwi-interacting RNA $(1.31 \%)$, transfer RNA (1.24\%), small nuclear RNA $(0.18 \%)$ and small nucleolar RNA $(0.01 \%)$ [65]. As mentioned above, Valadi et al. have reported that miRNA and mRNA are transported by EVs and that the latter species can undergo translation, thus indicating horizontal transfer of nucleic acids between cells [33]. Another study utilizing the reporter system under the control of the CRE recombinase, provided evidence for the transfer of EV-encapsulated CRE mRNA between hematopoietic system and the brain in response to inflammation [66]. Moreover, a growing body of research demonstrates that exosomes are enriched in small non-coding RNAs and thereby possibly participate in modulation of gene expression via transfer of these molecules $[37,61,67,68]$. Exosomal miRNAs such as miR-200 [69], miR-92a [70], miR-21 [71], miR-124a [72] are indicated to be involved in phys- 
iological and pathological processes: cancer metastasis, tumor angiogenesis, myocardial protection and modulation of synaptic activation, respectively. Curiously, lncRNAs and circRNAs have been detected in exosomes and reported to participate in carcinogenesis. For instance, IncRNA-UCA1 enclosed in exosomes secreted by hypoxic bladder cancer cells promoted tumor growth and epithelial-mesenchymal transition (EMT) [73], while circ-KLDHC10, present in serum-derived exosomes of patients with colorectal cancer was proposed as a new, potential biomarker of this disease [74]. It was demonstrated that sorting of RNAs into exosomes is selective as exosomal RNA profiles do not reflect these observed in parent cells $[33,75,76]$, however, the mechanism behind this process remains to be elucidated [67]. Several RNA-binding proteins (RBP) including HuR (ELAV-like protein 1; Hu-antigen R) [77], MEX3C (RNA-binding E3 ubiquitin-protein ligase) [78] and hnRNPA2B1(heterogeneous nuclear ribonucleoprotein A2B1) [79] were proposed to be involved in RNA sorting.

Studies have also demonstrated that exosomes can carry DNA, namely fragmented gDNA [80], mtDNA [64], as well as parasitic DNA [81]. The mechanism of exoDNA incorporation is still unknown, however, random sorting has been suggested [37]. Excitingly, Takahashi et al. have indicated that exosome release is crucial for cellular homeostasis maintenance, as a mechanism of harmful cytoplasmic DNA removal [82].

\section{Selected origins \\ Nervous System}

In 2006, Faure et al. have for the first time demonstrated exosome secretion from astrocytes and neurons in primary cortical culture in response to depolarization. The authors further suggested a lysosome-independent mechanism of receptor disposal in synapses [83]. Moving to glial cells, exosomes from Schwann cells play a role in axonal regeneration [84], while exosomes derived from oligodendrocytes contain proteolipid protein (PLP), myelin proteins and proteins associated with protection against oxidative stress [85]. In addition, oligodendrocytes release exosomes which can inhibit the processes of myelin sheath formation and oligodendrocyte differentiation [86]. It was also demonstrated that microglia-derived exosome release can be regulated by neurotransmitters - Glebov et al. highlighted a role for serotonin in this process stimulation of 5-HT receptors present in microglia results in secretion of exosomes containing insulin-degrading enzyme which can degrade amyloid- $\beta$ $(A \beta)$ [87]. As mentioned above, exosomes are also assigned a function as intracellular communication mediators. Exosomes derived from neuroblastoma cells are mainly internalized by astrocytes, while exosomes released from cortical neurons are captured by other neurons [88]. It was also reported that glutamate can influence oligodendrocyte-derived exosome internalization by neurons [89].

\section{Cardiovascular System}

As vesicles rich in various active components, exosomes can play their roles in intercellular communication essential for cardiovascular and arterial physiology. For instance, miR-21* encapsulated in exosomes transferred between cardiac fibroblasts and cardiac myocytes induces cardiomyocyte hypertrophy [90]. Chen et al. have reported upregulation of exosomal miR-21 in conditioned medium derived from OGD (oxygen-glucose deprivation)-treated cardiomyocytes and suggested its function in protection of cardiomyocytes against oxidative stress, fibroblast activation and promotion of angiogenesis in endothelial cells [91]. miR-126 released by endothelial-derived exosomes participates in vascular endothelial repair [92]. It was also demonstrated that, when in glucose-deprived conditions, cardiomyocytes (CMs) increase the production and release of exosomes, which comprise functional glucose transporters and glycolytic enzymes. These vesicles influenced the glucose uptake, glycolytic activity and pyruvate production when internalized by recipient endothelial cells (ECs) [93]. Exosomes secreted by cardiomyocytes, cardiac fibroblasts, platelets, endothelial cells, smooth muscle cells, macrophages and cardiac progenitor cells have been implicated in coronary artery disease, hypertrophy, cardiac regeneration, as well as atherosclerosis $[10,94,95]$.

\section{Reproductive system and development}

The female and male reproductive tracts, as well as placenta, secrete exosomes [96]. These EVs were detected in semen, amniotic fluid and breast milk, as mentioned above. The syncytiotrophoblast (STB) of human placenta produces and releases extracellular vesicles to the maternal blood, due to programmed cell death and blebbing. These MVs have mainly immunostimulatory and pro-inflammatory features. Simultaneously, STB synthesizes and secretes exosomes which are reported to have immunosuppressive functions. As it was demonstrated that STBMs (syntiotrophoblast-derived microvesicles) levels are elevated in the blood of patients with preeclampsia, the most common cause of materno-fetal illness, it is suggested that the imbalance between these microvesicles and exosomes may contribute to the development of the disease [96-98]. Moreover, it was shown that miRNAs of the chromosome 19 miRNA cluster are packed into trophoblast-derived exosomes and regulate immunity to viral infections [99]. Breast milk contains exosomes with immunomodulatory properties crucial for infant's health. For instance, incubation of milk exosomes with PBMC (peripheral blood mon- 
onuclear cells) resulted in an increase in the number of T-regulatory cells [22]. RNA-seq of seminal plasma-derived exosomes revealed an abundance of miRNAs such as miR-148a and let-7 family members, which are implicated in the reduction of cytokine secretion and expression of interleukins - IL10 and IL-13, respectively, thus possibly play a role in immunophysiology of the genital tract [21].

\section{Methods of exosome isolation}

Exosomes have a number of features that are used in numerous methods of their isolation from biological material. Physicochemical properties such as size, mass, density or the ability to interact with specific proteins allowed for the development and advance of several effective methods [100], with the recovery and purity of exosomes making it possible to most effectively determine their efficiency and accuracy. The purity of exosomes can be characterized through the analysis of the intensity of exosome markers using Western blot [101]. Purity is also defined by the ratio of the number of exosomal vesicles and the amount of proteins (particles per microgram) [102-104]. This information can be obtained using the bicinchoninic acid and NTA (Nanoparticle Tracing Analysis) assay. Regarding the recovery of exosomes, we can define it by the ratio of the treated exosome particles and the original exosome particles in the samples (which is also determined by NTA) [105]. Methods for isolating exosomes are listed below according to their properties from different categories.

\section{Size based isolation}

The size of the exosomes varies between 20 and $140 \mathrm{~nm}$ and is used in the size-based isolation method. Currently, size-based isolation mainly involves three different methods: size exclusion chromatography (SEC), sequence filtration and size dependent microfluidics [106-108]. These methods are relatively fast and do not require a lot of special equipment. However, it is sometimes difficult to separate exosomes of different sizes because of low resolution. SEC is based on the filtration of particles through a porous stationary phase. This phase consists of small, gel balls, the pores of which are specifically sized. As the sample passes through the stationary phase, large particles elute and small particles remain in the pores. When using sequential filtration mechanisms, procedures similar to normal filtration are used. The size and molecular weight of the isolated particles determine the filtration parameters. In separating exosomes, membrane filters with different molecular weight exclusion limits are used. The exosomes separated by such filtration are of high purity, taking into account the low manipulating forces [106]. The size-dependent microfluids are a separate methods, recently increasing in popularity [109]. In 2017, a viscoelastic microflow was used to separate exosomes from other extracellular vesicles [110]. The same system was also used to isolate exosomes obtained from foetal bovine serum. Due to its wide-ranging exosome separation, the size-dependent microfluidic system holds great promise for the future of exosome analysis. In turn, another method-asymmetric flow field-flow fractionation (AF4), could increase the above-mentioned resolution $[111,112]$. Thanks to AF4, small exosome vesicles and exomeres (very small nonmembranous nanoparticles) could be separated from large exosomes [113]. Furthermore, for even more accurate isolation, AF4 optimizations were conducted, combined with a multi-detection system based on UV and multiangle light scattering. Thanks to this combination, it became possible to distinguish new subsequent groups of exosome sizes (average size $113 \mathrm{~nm}$ and $23 \mathrm{~nm}$ ) [113]. While relatively accurate, these methods are not highly specific. While exosome recovery can reach over $80 \%$, the procedures certainly require further improvement and refinement.

\section{Immunoaffinity}

As mentioned above, a number of specific membrane proteins are found on the surface of exosomes. These include CD82, CD81, CD61 and CD9, annexin, programmed cell death 6 interacting protein, RAB5 and epithelial cellular adhesion molecule (EPCAM). These proteins can be used as specific markers for the isolation of exosomes. Hence, several isolation techniques are based on immunoaffinity [114-116]. The construction of superparamagnetic immunoaffinity nanoparticles turned out to be an interesting method, combining antibodies with superparamagnetic particles and confocal laser scanning microscopy to confirm structural and functional integrity [117]. The results showed that the immunoaffinity superparamagnetic nanoparticle method performed excellently in maintaining the functional and structural integrity of exosomes. A rather large downside to the use of immunoaffinity is the availability and high cost of antibodies. In addition, the number of exosomes isolated may be underestimated as some antibodies may not be expressed on the exosome surface [117].

\section{Density-based isolation}

UC or ultracentrifugation is the most common method of exosome isolation based on their density. This most widely used technique is often considered the "gold standard" [118]. It was first used in 1987 and has been continuously improved ever since [119]. After more than 20 years, it has been proven that it takes at least five UC cycles to remove non-exosomal proteins [120]. The most universal UC scheme is as follows. Cells, large EVs and cellular debris are separated in the first place by not very high centrifugal forces $(\leqq 10,000 \times$ g). Next, 
exosomes are selected due to the long centrifugation time ( $~ 70 \mathrm{~min})$ and high centrifugal forces $(100,000-200,000 \times \mathrm{g})$ needed for their separation. The exosome pellet is washed with phosphate buffered saline (PBS) to remove residual proteins. The purified exosomes are stored at $-80^{\circ} \mathrm{C}$, suspended in a fresh portion of PBS [76]. The sucrose density gradient centrifugation method is also used quite often but is generally considered outdated. It is a density-based method of isolating exosomes that $=$ have a density of 1.15 to $1.19 \mathrm{~g} / \mathrm{ml}$ [121]. While it is relatively easy to isolate exosomes with these methods, they can only achieve a relatively low purity of $10^{8}-10^{9}$ particles per microgram. It is also quite time consuming and has a recovery of $10 \%$ to $80 \%$ due to the likely damage to the vesicle. Besides, the coexistence of other large biomolecules, protein aggregates and other particles of similar density is inevitable and may cause bias in the analysis.

\section{Co-precipitation method}

Every year, polymers are gaining more and more popularity in the scientific community. Taking advantage of their many properties, they can be used to co-precipitate lipid molecules and hydrophobic proteins. In 1960, it was discovered that polyethylene glycol (PEG) could be used to purify and isolate viruses [122]. Due to some biophysical similarities of viruses to exosomes, PEG can also be used in their isolation. This procedure can be performed with easy-to-use commercial kits such as ExoQuick ${ }^{\mathrm{T}}$. Many scientists have chosen this method in their research because it does not require long ultracentrifugation, as well as is relatively fast and low-effort $[123,124]$.

While not as popular, other innovative sorting methods have also been developed. These are, for example, electromagnetic, electrophoretic or acoustic methods [125-127]. Some time ago, a novel chip was also designed, allowing for the use of the phenomenon of alternating current electrokinetics (ACE) for exosome isolation [128].

As can be seen above, a number of methods have been developed to isolate exosomes since the beginning of their rise to popularity. However, there is no single method that covers all the expectations of researchers, so it is important to know and skilfully combine them, to obtain repeatable and expected outcomes.

\section{Application of exosomes in human therapies}

A common ground for the researchers' interest in exosomal analyses is the role of exosomes as carriers of disease biomarkers. For example, exosomes in both plasma and cerebrospinal fluid (CSF) have been found to contain alpha-synuclein, a protein directly related to Parkinson's disease $[129,130]$. As an example, Ilario Giusti and his team focused on exosomes as markers of glioma [131]. Furthermore, exosomes isolated from urine have shown the ability to reflect the state of acute renal failure [132]. Markers of pancreatic cancer and lung cancer were also found in exosomes $[18,133]$. Hence, the use of exosomes as potential biomarkers is very promising as these vesicles are found in most of the parts of human organism. Their presence in body fluids, such as blood and urine, allows the use of minimally invasive methods, e.g. liquid biopsy, to diagnose and monitor the patient's response to treatment in real time [134]. The ability of exosomes to monitor the patient's response is another potential clinical application of these vesicles, as confirmed in previous studies [135]. If a marker is directly correlated with a disease state, and treatment of the patient produces the expected, visible results, the change in the presence of biomarkers (exosomes) should be monitored during treatment. Additionally, it has been suggested that exosomes can be used in vaccine development and for other immunological-related purposes [136,137]. Since one of the characteristics of exosomes is the ability to present antigens, it could also be put to good use. Exosomes have a long half-life, the human body does not perceive them as foreign bodies, they can not only penetrate cell membranes, but also target specific types of cells, which makes them even better candidates for the above-mentioned applications [138]. Furthermore, due to their characteristics, they are also ideal for the design of drug delivery systems aimed at specific targets [139]. While the development of a method for introducing RNA and proteins into exosomes and targeting them to a specific region of the body is still ongoing, the ability to load both protein and genetic material into the exosomes is yet another strength of these vesicles. It has also been proven that mesenchymal stem cell exosomes can act alone as a therapeutic unit to help reduce and regenerate tissue damage [140-142]. Exosomes have been also implicated in the development of neurodegenerative diseases. Reports proposing exosomes' participation in protein aggregates clearance, which would be indicative of neuroprotective function, as well as those describing their role in spreading of unfolded or misfolded proteins in proteinopathies, can both be found. As an example, positive relations between exosomes' release and intercellular transfer of infective prions in Creutzfeldt-Jakob disease has been demonstrated [143]. As for Alzheimer's disease (AD), exosomes containing tau protein have been detected in CSF of early onset cases. It was demonstrated, both in vitro and in vivo, that exosome secretion by microglia serves as means of tau propagation [144]. Rajendran et al. reported the presence of $A \beta$ in exosomes derived from the $\mathrm{N} 2 \mathrm{a}$ cell line and demonstrated the accumulation of exosomal proteins in plaques of AD patients' brains 
[145]. Furthermore, Yuyama et al. highlighted the role of neuronal exosomes in $A \beta$ clearance. They detected $A \beta$ in CSF-derived exosomes fraction and observed decrease of its level in relation to aging, as well as performed an intracerebral infusion of neuronal exosomes which resulted in decrease in $A \beta$ and amyloid deposition in the brains of APP transgenic mice. Their results implicated possible role of neuronal exosomes in $\mathrm{A} \beta$ clearance and provides a suggestion that their deregulation might contribute to $A \beta$ accumulation and therefore to $A D$ [146]. Exosomes containing $\alpha$-synuclein and Lewy bodies were isolated from CSF of patients with Parkinson's disease (PD) and dementia, respectively [147]. Emmanouilidou et al. demonstrated that $\alpha$-synculein can be released by neuronal cells in exosomes in a $\mathrm{Ca}^{2+}$-dependent manner, as well as that these exosomes induced neuronal recipient cell death [148]. Moreover, a study by Fraser et al. demonstrated elevated levels of autophosporylated Ser(P)-1292 LRRK2 in urine of patients with idiopathic Parkinson's disease and its correlation with cognitive impairment severity and difficulty in daily task performance [149]. SOD1 and TPD-43, which are thought to contribute to ALS pathogenesis by adopting abnormal conformation are also contained in exosomes. In turn, null mutations in GRN gene, associated with certain cases of frontotemporal dementia lead to significant reduction in exosome release and consequently to a decrease in progranulin levels, implicated in the pathogenesis of FTD [150]. The role of exosomes in wound healing is also worth elaborating, as it is already known that the exosome, an important paracrine factor in intercellular communication, modulates the molecular activity of recipient cells [151]. The role of stem cell-derived exosomes in promoting tissue repair has also been described in several sources. According to the available information, exosomes derived from human umbilical mesenchymal stem cells alleviated acute ischemic damage to the heart muscle [152], while exosomes derived from human adipose tissue mesenchymal stem cells accelerated the healing of skin wounds by optimizing certain features of fibroblasts [153]. In turn, exosomes derived from human umbilical cord mesenchymal stem cells attenuated liver fibrosis [154], while exosomal microRNAs isolated from umbilical mesenchymal stem cells inhibited myofibroblast differentiation by inhibiting the transforming growth factor- $\beta$ / Smad2 pathway [155]. However, most interestingly, it was also found that local injection of exosomes promotes the regeneration of damaged tissue [153]. Exosomes also carry functional proteins, mRNAs and microRNAs to neighboring cells, and thus undoubtedly serve as mediators of intercellular communication [156].

As demonstrated above, there is a wide range of potential uses of exosomes in a clinical setting. However, more standardized methods of isolating and analysing exosomes are needed to meet the regulatory requirements of the FDA (U.S. Food and Drug Administration) and other regulatory agencies regarding their use as biomarkers, vaccines, drug delivery vehicles, and therapeutic tools in general.

\section{Ethical approval}

The conducted research is not related to either human or animal use.

\section{Acknowledgments}

Not applicable.

\section{Corresponding author}

Marta Dyszkiewicz-Konwińska, Department of Biomaterials and Experimental Dentistry, 70 Bukowska St., 60-812 Poznań, Poland and Department of Anatomy, Poznan University of Medical Sciences, 6 Święcickiego St., 60-781 Poznań, Poland, Tel./Fax: +48 61 8546565, e-mail: m.dyszkiewicz@ump.edu.pl.

\section{Conflict of interest statement}

The authors declare they have no conflict of interest.

\section{References:}

1. Trams EG, Lauter CJ, Norman Salem J, Heine U. Exfoliation of membrane ecto-enzymes in the form of micro-vesicles. BBA - Biomembr. 1981;645:63-70; DOI:10.1016/0005-2736(81)90512-5.

2. Żebryk P, Puszczewicz Katedra Klinika Reumatologii Chorób Wewnętrznych Uniwersytetu Medycznego im Karola Marcinkowskiego Poznaniu M. Autoprzeciwciała w twardzinie układowej* Autoantibodies in systemic sclerosis. Postepy Hig Med Dosw. 2015:654-60.

3. Carpousis AJ. The Escherichia coli RNA degradosome: structure, function and relationship in other ribonucleolytic multienzyme complexes. Biochem Soc Trans. 2002;30:150-5; DOI:10.1042/bst0300150.

4. Shen V, Kiledjian M. A View to a Kill: Structure of the RNA Exosome. Cell. 2006;127:1093-5; DOI:10.1016/j.cell.2006.11.035.

5. Théry C, Zitvogel L, Amigorena S. Exosomes: Composition, biogenesis and function. Nat Rev Immunol. 2002;2:569-79; DOI:10.1038/nri855.

6. Harrell CR, Jovicic N, Djonov V, Arsenijevic N, Volarevic V. Mesenchymal Stem Cell-Derived Exosomes and Other Extracellular Vesicles as New Remedies in the Therapy of Inflammatory Diseases. Cells. 2019;8; DOI:10.3390/cells8121605.

7. Song M, Han L, Chen FF, Wang D, Wang F, Zhang L, Wang ZH, Zhong M, Tang MX, Zhang W. Adipocyte-derived exosomes carrying sonic hedgehog mediate M1 macrophage polarization-induced insulin resistance via Ptch and PI3K pathways. Cell Physiol Biochem. 2018; DOI:10.1159/000492252.

8. Yuan Y, Du W, Liu J, Ma W, Zhang L, Du Z, Cai B. Stem cell-derived exosome in cardiovascular diseases: Macro roles of micro particles. Front Pharmacol. 2018; DOI:10.3389/fphar.2018.00547.

9. Hirsch E, Hilfiker-Kleiner D, Balligand JL, Tarone G, De Windt L, Bauersachs J, Ferdinandy P, Davidson S, Hausenloy DJ, Schulz R. Interaction of the heart and its close and distant neighbours: Report of the Meeting of the ESC Working Groups Myocardial Function and Cellular Biology. Cardiovasc Res. 2013; DOI:10.1093/cvr/cvt179.

10. Kishore R, Garikipati VNS, Gumpert A. Tiny Shuttles for Information Transfer: Exosomes in Cardiac Health and Disease. J Cardiovasc Transl Res. 2016; DOI:10.1007/s12265-016-9682-4.

11. Gupta A, Pulliam L. Exosomes as mediators of neuroinflammation. J Neuroinflammation. 2014; DOI:10.1186/1742-2094-11-68.

12. Janas AM, Sapoń K, Janas T, Stowell MHB, Janas T. Exosomes and other extracellular vesicles in neural cells and neurodegenerative diseases. Biochim Biophys Acta - Biomembr. 2016;1858:1139-51; DOI:10.1016/j.bbamem.2016.02.011.

13. Sims B, Gu L, Krendelchtchikov A, Matthews QL. Neural stem cell-derived exosomes mediate viral entry. Int J Nanomedicine. 2014; DOI:10.2147/IJN.S70999.

14. Nojima H, Freeman CM, Schuster RM, Japtok L, Kleuser B, Edwards MJ, Gulbins E, Lentsch AB. Hepatocyte exosomes mediate liver repair and regeneration via sphingosine-1-phosphate. J Hepatol. 2016; DOI:10.1016/j.jhep.2015.07.030.

15. Dinh PUC, Paudel D, Brochu H, Popowski KD, Gracieux MC, Cores J, Huang K, Hensley MT, Harrell E, Vandergriff AC, George AK, Barrio RT Hu S, Allen TA, Blackburn K, Caranasos TG, Peng X, Schnabel L V., Adler $\mathrm{KB}$, Lobo LJ, Goshe MB, Cheng K. Inhalation of lung spheroid cell se- 
cretome and exosomes promotes lung repair in pulmonary fibrosis. Nat Commun. 2020; DOI:10.1038/s41467-020-14344-7.

16. Wolfers J, Lozier A, Raposo G, Regnault A, Théry C, Masurier C, Flament C, Pouzieux S, Faure F, Tursz T, Angevin E, Amigorena S, Zitvogel L. Tumor-derived exosomes are a source of shared tumor rejection antigens for CTL cross-priming. Nat Med. 2001; DOI:10.1038/85438.

17. Keller S, Ridinger J, Rupp AK, Janssen JWG, Altevogt P. Body fluid derived exosomes as a novel template for clinical diagnostics. J Transl Med. 2011; DOI:10.1186/1479-5876-9-86.

18. Melo SA, Luecke LB, Kahlert C, Fernandez AF, Gammon ST, Kaye J, LeBleu VS, Mittendorf EA, Weitz J, Rahbari N, Reissfelder C, Pilarsky C, Fraga MF, Piwnica-Worms D, Kalluri R. Glypican-1 identifies cancer exosomes and detects early pancreatic cancer. Nature. 2015;523:177-82; DOI:10.1038/nature14581.

19. Chiasserini D, Van Weering JRT, Piersma SR, Pham T V., Malekzadeh A Teunissen CE, De Wit H, Jiménez CR. Proteomic analysis of cerebrospinal fluid extracellular vesicles: A comprehensive dataset. J Proteomics. 2014; DOI:10.1016/j.jprot.2014.04.028.

20. Hood JL. The association of exosomes with lymph nodes. Semin Cell Dev Biol. 2017; DOI:10.1016/j.semcdb.2016.12.002.

21. Vojtech L, Woo S, Hughes S, Levy C, Ballweber L, Sauteraud RP, Strobl J, Westerberg K, Gottardo R, Tewari M, Hladik F. Exosomes in human semen carry a distinctive repertoire of small non-coding RNAs with potential regulatory functions. Nucleic Acids Res. 2014; D0I:10.1093/ nar/gku347.

22. Admyre C, Johansson SM, Qazi KR, Filén J-J, Lahesmaa R, Norman M, Neve EPA, Scheynius A, Gabrielsson S. Exosomes with Immune Modulatory Features Are Present in Human Breast Milk. J Immunol. 2007; DOI:10.4049/jimmunol.179.3.1969.

23. Severino V, Dumonceau JM, Delhaye M, Moll S, Annessi-Ramseyer I, Robin X, Frossard JL, Farina A. Extracellular Vesicles in Bile as Markers of Malignant Biliary Stenoses. Gastroenterology. 2017; DOI:10.1053/j. gastro.2017.04.043.

24. Admyre C, Grunewald J, Thyberg J, Bripenäck S, Tornling G, Eklund A Scheynius A, Gabrielsson S. Exosomes with major histocompatibility complex class II and co-stimulatory molecules are present in human BAL fluid. Eur Respir J. 2003; DOI:10.1183/09031936.03.00041703.

25. Foers AD, Chatfield S, Dagley LF, Scicluna BJ, Webb AI, Cheng L, Hill AF Wicks IP, Pang KC. Enrichment of extracellular vesicles from human synovial fluid using size exclusion chromatography. J Extracell Vesicles. 2018; DOI:10.1080/20013078.2018.1490145.

26. Kagota S, Taniguchi K, Lee SW, Ito Y, Kuranaga Y, Hashiguchi Y, Inomata Y, Imai Y, Tanaka R, Tashiro K, Kawai M, Akao Y, Uchiyama K. Analysis of extracellular vesicles in gastric juice from gastric cancer patients. Int Mol Sci. 2019; DOI:10.3390/ijms20040953.

27. Grigor'eva AE, Tamkovich SN, Eremina A V., Tupikin AE, Kabilov MR Chernykh V V., Vlassov V V., Laktionov PP, Ryabchikova EI. Exosomes in tears of healthy individuals: Isolation, identification, and characterization. Biochem Suppl Ser B Biomed Chem. 2016; DOI:10.1134/ S1990750816020049.

28. Andre F, Schartz NEC, Movassagh M, Flament C, Pautier P, Morice P, Pomel C, Lhomme C, Escudier B, Le Chevalier T, Tursz T, Amigorena S, Raposo G, Angevin E, Zitvogel L. Malignant effusions and immunogenic tumour-derived exosomes. Lancet. 2002; DOI:10.1016/ S0140-6736(02)09552-1.

29. Trams EG, Lauter CJ, Norman Salem J, Heine U. Exfoliation of mem brane ecto-enzymes in the form of micro-vesicles. BBA - Biomembr. 1981; DOI:10.1016/0005-2736(81)90512-5.

30. Harding C, Heuser J, Stahl P. Receptor-mediated endocytosis of transferrin and recycling of the transferrin receptor in rat reticulocytes. Cell Biol. 1983; DOI:10.1083/jcb.97.2.329.

31. Pan BT, Teng K, Wu C, Adam M, Johnstone RM. Electron microscopic evidence for externalization of the transferrin receptor in vesicular form in sheep reticulocytes. J Cell Biol. 1985; DOI:10.1083/jcb.101.3.942.

32. Raposo G, Nijman HW, Stoorvogel W, Leijendekker R, Harding C V., Melief CJM, Geuze HJ. B lymphocytes secrete antigen-presenting vesicles. J Exp Med. 1996; DOI:10.1084/jem.183.3.1161.

33. Valadi H, Ekström K, Bossios A, Sjöstrand M, Lee JJ, Lötvall JO. Exosome-mediated transfer of mRNAs and microRNAs is a novel mechanism of genetic exchange between cells. Nat Cell Biol. 2007;9:654-9; DOI:10.1038/ncb1596.

34. Hessvik NP, Llorente A. Current knowledge on exosome biogenesis and release. Cell Mol Life Sci. 2018;75:193-208; DOI:10.1007/ s00018-017-2595-9.

35. Kalluri R, LeBleu VS. The biology, function, and biomedical applications of exosomes. Science (80-). 2020; DOI:10.1126/science.aau6977.

36. Mathieu M, Martin-Jaular L, Lavieu G, Théry C. Specificities of secretion and uptake of exosomes and other extracellular vesicles for cell-to-cell communication. Nat Cell Biol. 2019;21:9-17; DOI:10.1038/ s41556-018-0250-9.
37. Bebelman MP, Smit MJ, Pegtel DM, Baglio SR. Biogenesis and function of extracellular vesicles in cancer. Pharmacol Ther. 2018; DOI:10.1016/j. pharmthera.2018.02.013.

38. Ciardiello C, Cavallini L, Spinelli C, Yang J, Reis-Sobreiro M, Candia P De, Minciacchi VR, Di Vizio D. Focus on extracellular vesicles: New frontiers of cell-to-cell communication in cancer. Int J Mol Sci. 2016; DOI:10.3390/ijms17020175.

39. Edgar JR, Manna PT, Nishimura S, Banting G, Robinson MS. Tetherin is an exosomal tether. Elife. 2016; DOI:10.7554/eLife.17180.

40. Mulcahy LA, Pink RC, Carter DRF. Routes and mechanisms of extracellular vesicle uptake. J Extracell Vesicles. 2014;3; DOI:10.3402/jev. v3.24641.

41. Fonseca P, Vardaki I, Occhionero A, Panaretakis T. Metabolic and Signaling Functions of Cancer Cell-Derived Extracellular Vesicles. Int. Rev. Cell Mol. Biol., 2016; DOI:10.1016/bs.ircmb.2016.04.004.

42. Fitzner D, Schnaars M, Van Rossum D, Krishnamoorthy G, Dibaj P, Bakhti M, Regen T, Hanisch UK, Simons M. Selective transfer of exosomes from oligodendrocytes to microglia by macropinocytosis. J Cell Sci. 2011;124:447-58; DOI:10.1242/jcs.074088.

43. Horibe S, Tanahashi T, Kawauchi S, Murakami Y, Rikitake Y. Mechanism of recipient cell-dependent differences in exosome uptake. BMC Cancer. 2018;18:47; DOI:10.1186/s12885-017-3958-1.

44. Tauro BJ, Greening DW, Mathias RA, Ji H, Mathivanan S, Scott AM, Simpson RJ. Comparison of ultracentrifugation, density gradient separation, and immunoaffinity capture methods for isolating human colon cancer cell line LIM1863-derived exosomes. Methods. 2012; DOI:10.1016/j. ymeth.2012.01.002

45. Shao H, Im H, Castro CM, Breakefield X, Weissleder R, Lee H. New Technologies for Analysis of Extracellular Vesicles. Chem Rev. 2018, DOI:10.1021/acs.chemrev.7b00534.

46. Zaborowski MP, Balaj L, Breakefield XO, Lai CP. Extracellular Vesicles: Composition, Biological Relevance, and Methods of Study. Bioscience. 2015; DOI:10.1093/biosci/biv084.

47. Shin S, Han D, Park MC, Mun JY, Choi J, Chun H, Kim S, Hong JW. Separation of extracellular nanovesicles and apoptotic bodies from cancer cell culture broth using tunable microfluidic systems. Sci Rep. 2017 DOI:10.1038/s41598-017-08826-w.

48. Greening DW, Xu R, Ji H, Tauro BJ, Simpson RJ. A protocol for exosome isolation and characterization: Evaluation of ultracentrifugation, density-gradient separation, and immunoaffinity capture methods. Methods Mol. Biol., 2015; DOI:10.1007/978-1-4939-2550-6_15.

49. Dragovic RA, Gardiner C, Brooks AS, Tannetta DS, Ferguson DJP, Hole P, Carr B, Redman CWG, Harris AL, Dobson PJ, Harrison P, Sargent IL. Sizing and phenotyping of cellular vesicles using Nanoparticle Tracking Analysis. Nanomedicine Nanotechnology, Biol Med. 2011; DOI:10.1016/j.nano.2011.04.003.

50. Keerthikumar S, Chisanga D, Ariyaratne D, Al Saffar H, Anand S, Zhao K, Samuel M, Pathan M, Jois M, Chilamkurti N, Gangoda L, Mathivanan S. ExoCarta: A Web-Based Compendium of Exosomal Cargo. J Mol Biol. 2016; DOI:10.1016/j.jmb.2015.09.019.

51. Wen SW, Lima LG, Lobb RJ, Norris EL, Hastie ML, Krumeich S, Möller A. Breast Cancer-Derived Exosomes Reflect the Cell-of-Origin Phenotype. Proteomics. 2019; DOI:10.1002/pmic.201800180.

52. Vincent-Schneider H, Stumptner-Cuvelette P, Lankar D, Pain S, Raposo G, Benaroch P, Bonnerot C. Exosomes bearing HLA-DR1 molecules needs dendritic cells to efficiently stimulate specific T cells. Int Immunol. 2002; DOI:10.1093/intimm/dxf048.

53. Potolicchio I, Carven GJ, Xu X, Stipp C, Riese RJ, Stern LJ, Santambrogio L. Proteomic Analysis of Microglia-Derived Exosomes: Metabolic Role of the Aminopeptidase CD13 in Neuropeptide Catabolism. J Immunol. 2005; DOI:10.4049/jimmunol.175.4.2237.

54. Choi D, Montermini L, Kim DK, Meehan B, Roth FP, Rak J. The impact of oncogenic egfrviii on the proteome of extracellular vesicles released from glioblastoma cells. Mol Cell Proteomics. 2018; DOI:10.1074/mcp. RA118.000644.

55. Zhang Y, Liu Y, Liu H, Tang WH. Exosomes: Biogenesis, biologic function and clinical potential. Cell Biosci. 2019; DOI:10.1186/ s13578-019-0282-2.

56. H. Rashed M, Bayraktar E, K. Helal G, Abd-Ellah M, Amero P, Chavez-Reyes A, Rodriguez-Aguayo C. Exosomes: From Garbage Bins to Promising Therapeutic Targets. Int J Mol Sci. 2017;18:538; DOI:10.3390/ ijms18030538.

57. Skotland T, Hessvik NP, Sandvig K, Llorente A. Exosomal lipid composition and the role of ether lipids and phosphoinositides in exosome biology. J Lipid Res. 2019; DOI:10.1194/jlr.R084343.

58. Skotland T, Sandvig K, Llorente A. Lipids in exosomes: Current knowledge and the way forward. Prog Lipid Res. 2017; DOI:10.1016/j. plipres.2017.03.001.

59. Record M, Carayon K, Poirot M, Silvente-Poirot S. Exosomes as new vesicular lipid transporters involved in cell-cell communication and 
various pathophysiologies. Biochim Biophys Acta - Mol Cell Biol Lipids. 2014; DOI:10.1016/j.bbalip.2013.10.004.

60. Xiang X, Poliakov A, Liu C, Liu Y, Deng Z Bin, Wang J, Cheng Z, Shah S V., Wang GJ, Zhang L, Grizzle WE, Mobley J, Zhang HG. Induction of myeloid-derived suppressor cells by tumor exosomes. Int J Cancer. 2009; DOI:10.1002/ijc.24249.

61. Van Balkom BWM, Eisele AS, Michiel Pegtel D, Bervoets S, Verhaar MC. Quantitative and qualitative analysis of small RNAs in human endothelial cells and exosomes provides insights into localized RNA processing, degradation and sorting. J Extracell Vesicles. 2015; DOI:10.3402/jev. v4.26760.

62. Fanale D, Taverna S, Russo A, Bazan V. Circular RNA in exosomes. Adv. Exp. Med. Biol., 2018; DOI:10.1007/978-981-13-1426-1_9.

63. Bellingham SA, Coleman BM, Hill AF. Small RNA deep sequencing reveals a distinct miRNA signature released in exosomes from prion-infected neuronal cells. Nucleic Acids Res. 2012; DOI:10.1093/nar/gks832.

64. Guescini M, Genedani S, Stocchi V, Agnati LF. Astrocytes and Glioblastoma cells release exosomes carrying mtDNA. J Neural Transm. 2010 DOI:10.1007/s00702-009-0288-8.

65. Huang X, Yuan T, Tschannen M, Sun Z, Jacob H, Du M, Liang M, Dittmar RL, Liu Y, Liang M, Kohli M, Thibodeau SN, Boardman L, Wang L. Characterization of human plasma-derived exosomal RNAs by deep sequencing. BMC Genomics. 2013; DOI:10.1186/1471-2164-14-319.

66. Ridder K, Keller S, Dams M, Rupp AK, Schlaudraff J, Del Turco D, Starmann J, Macas J, Karpova D, Devraj K, Depboylu C, Landfried B, Arnold B, Plate KH, Höglinger G, Sültmann H, Altevogt P, Momma S. Extracellular Vesicle-Mediated Transfer of Genetic Information between the Hematopoietic System and the Brain in Response to Inflammation. PLoS Biol. 2014; DOI:10.1371/journal.pbio.1001874

67. Zhang J, Li S, Li L, Li M, Guo C, Yao J, Mi S. Exosome and exosomal microRNA: Trafficking, sorting, and function. Genomics, Proteomics Bioinforma. 2015; DOI:10.1016/j.gpb.2015.02.001

68. Goldie BJ, Dun MD, Lin M, Smith ND, Verrills NM, Dayas C V., Cairns MJ. Activity-associated miRNA are packaged in Map1b-enriched exosomes released from depolarized neurons. Nucleic Acids Res. 2014; DOI:10.1093/nar/gku594.

69. Le MTN, Hamar P, Guo C, Basar E, Perdigão-Henriques R, Balaj L, Lieberman J. MiR-200-containing extracellular vesicles promote breast cancer cell metastasis. J Clin Invest. 2014; DOI:10.1172/JCI75695.

70. Umezu T, Ohyashiki K, Kuroda M, Ohyashiki JH. Leukemia cell to endothelial cell communication via exosomal miRNAs. Oncogene. 2013; DOI:10.1038/onc.2012.295

71. Xiao J, Pan Y, Li XH, Yang XY, Feng YL, Tan HH, Jiang L, Feng J, Yu XY Cardiac progenitor cell-derived exosomes prevent cardiomyocytes apoptosis through exosomal miR-21 by targeting PDCD4. Cell Death Dis. 2016; DOI:10.1038/cddis.2016.181.

72. Morel L, Regan M, Higashimori H, Ng SK, Esau C, Vidensky S, Rothstein J, Yang Y. Neuronal exosomal mirna-dependent translational regulation of astroglial glutamate transporter glt1. J Biol Chem. 2013, DOI:10.1074/jbc.M112.410944.

73. Xue M, Chen W, Xiang A, Wang R, Chen H, Pan J, Pang H, An H, Wang $\mathrm{X}$, Hou H, Li X. Hypoxic exosomes facilitate bladder tumor growth and development through transferring long non-coding RNA-UCA1. Mol Cancer. 2017; DOI:10.1186/s12943-017-0714-8.

74. Li Y, Zheng Q, Bao C, Li S, Guo W, Zhao J, Chen D, Gu J, He X, Huang S. Circular RNA is enriched and stable in exosomes: A promising biomarker for cancer diagnosis. Cell Res. 2015;25:981-4; DOI:10.1038/ cr.2015.82.

75. Mittelbrunn M, Gutiérrez-Vázquez C, Villarroya-Beltri C, González S, Sánchez-Cabo F, González MÁ, Bernad A, Sánchez-Madrid F. Unidirectional transfer of microRNA-loaded exosomes from $\mathrm{T}$ cells to antigen -presenting cells. Nat Commun. 2011; DOI:10.1038/ncomms1285.

76. Skog J, Würdinger T, van Rijn S, Meijer DH, Gainche L, Curry WT, Carter BS, Krichevsky AM, Breakefield XO. Glioblastoma microvesicles transport RNA and proteins that promote tumour growth and provide diagnostic biomarkers. Nat Cell Biol. 2008;10:1470-6; DOI:10.1038/ncb1800.

77. Mukherjee K, Ghoshal B, Ghosh S, Chakrabarty Y, Shwetha S, Das S, Bhattacharyya SN. Reversible HuR-micro RNA binding controls extracellular export of miR-122 and augments stress response. EMBO Rep. 2016; DOI:10.15252/embr.201541930.

78. Lu P, Li H, Li N, Singh RN, Bishop CE, Chen X, Lu B. MEX3C interacts with adaptor-related protein complex 2 and involves in miR-451a exosomal sorting. PLoS One. 2017; DOI:10.1371/journal.pone.0185992.

79. Villarroya-Beltri C, Gutiérrez-Vázquez C, Sánchez-Cabo F, Pérez-Hernández D, Vázquez J, Martin-Cofreces N, Martinez-Herrera DJ, Pascual-Montano A, Mittelbrunn M, Sánchez-Madrid F. Sumoylated hnRNPA2B1 controls the sorting of miRNAs into exosomes through binding to specific motifs. Nat Commun. 2013; DOI:10.1038/ncomms3980.
80. Thakur BK, Zhang H, Becker A, Matei I, Huang Y, Costa-Silva B, Zheng Y, Hoshino A, Brazier H, Xiang J, Williams C, Rodriguez-Barrueco R, Silva JM, Zhang W, Hearn S, Elemento O, Paknejad N, Manova-Todorova $\mathrm{K}$, Welte K, Bromberg J, Peinado H, Lyden D. Double-stranded DNA in exosomes: A novel biomarker in cancer detection. Cell Res. 2014; DOI:10.1038/cr.2014.44.

81. Sisquella X, Ofir-Birin Y, Pimentel MA, Cheng L, Abou Karam P, Sampaio NG, Penington JS, Connolly D, Giladi T, Scicluna BJ, Sharples RA, Waltmann A, Avni D, Schwartz E, Schofield L, Porat Z, Hansen DS, Papenfuss AT, Eriksson EM, Gerlic M, Hill AF, Bowie AG, Regev-Rudzki N. Malaria parasite DNA-harbouring vesicles activate cytosolic immune sensors. Nat Commun. 2017; DOI:10.1038/s41467-017-02083-1.

82. Takahashi A, Okada R, Nagao K, Kawamata Y, Hanyu A, Yoshimoto S, Takasugi M, Watanabe S, Kanemaki MT, Obuse C, Hara E. Exosomes maintain cellular homeostasis by excreting harmful DNA from cells. Nat Commun. 2017; DOI:10.1038/ncomms15287.

83. Fauré J, Lachenal G, Court M, Hirrlinger J, Chatellard-Causse C, Blot B, Grange J, Schoehn G, Goldberg Y, Boyer V, Kirchhoff F, Raposo G, Garin J, Sadoul R. Exosomes are released by cultured cortical neurones. Mol Cell Neurosci. 2006; DOI:10.1016/j.mcn.2005.12.003.

84. Lopez-Verrilli MA, Picou F, Court FA. Schwann cell-derived exosomes enhance axonal regeneration in the peripheral nervous system. Glia. 2013; DOI:10.1002/glia.22558.

85. Budnik V, Ruiz-Cañada C, Wendler F. Extracellular vesicles round off communication in the nervous system. Nat Rev Neurosci. 2016; DOI:10.1038/nrn.2015.29.

86. Bakhti M, Winter C, Simons M. Inhibition of myelin membrane sheath formation by oligodendrocyte-derived exosome-like vesicles. J Biol Chem. 2011; DOI:10.1074/jbc.M110.190009.

87. Glebov K, Löchner M, Jabs R, Lau T, Merkel O, Schloss P, Steinhäuser C, Walter J. Serotonin stimulates secretion of exosomes from microglia cells. Glia. 2015; DOI:10.1002/glia.22772.

88. Chivet M, Javalet C, Laulagnier K, Blot B, Hemming FJ, Sadoul R. Exosomes secreted by cortical neurons upon glutamatergic synapse activation specifically interact with neurons. J Extracell Vesicles. 2014;3; DOI:10.3402/jev.v3.24722.

89. Fröhlich D, Kuo WP, Frühbeis C, Sun JJ, Zehendner CM, Luhmann HJ, Pinto S, Toedling J, Trotter J, Krämer-Albers EM. Multifaceted effects of oligodendroglial exosomes on neurons: Impact on neuronal firing rate, signal transduction and gene regulation. Philos Trans R Soc B Biol Sci. 2014; DOI:10.1098/rstb.2013.0510.

90. Bang C, Batkai S, Dangwal S, Gupta SK, Foinquinos A, Holzmann A, Jus A, Remke J, Zimmer K, Zeug A, Ponimaskin E, Schmiedl A, Yin X, Mayr M, Halder R, Fischer A, Engelhardt S, Wei Y, Schober A, Fiedler J, Thum T. Cardiac fibroblast-derived microRNA passenger strand-enriched exosomes mediate cardiomyocyte hypertrophy. J Clin Invest. 2014; DOI:10.1172/JCI70577.

91. Chen C-H, Hsu S-Y, Chiu C-C, Leu S. MicroRNA-21 Mediates the Protective Effect of Cardiomyocyte-Derived Conditioned Medium on Ameliorating Myocardial Infarction in Rats. Cells. 2019; DOI:10.3390/ cells8080935.

92. Jansen F, Yang X, Hoelscher M, Cattelan A, Schmitz T, Proebsting S, Wenzel D, Vosen S, Franklin BS, Fleischmann BK, Nickenig G, Werner N. Endothelial microparticle-mediated transfer of microRNA-126 promotes vascular endothelial cell repair via spred 1 and is abrogated in glucose-damaged endothelial microparticles. Circulation. 2013; DOI:10.1161/ CIRCULATIONAHA.113.001720.

93. Garcia NA, Moncayo-Arlandi J, Sepulveda P, Diez-Juan A. Cardiomyocyte exosomes regulate glycolytic flux in endothelium by direct transfer of GLUT transporters and glycolytic enzymes. Cardiovasc Res. 2016; DOI:10.1093/cvr/cvv260.

94. Ibrahim A, Marbán E. Exosomes: Fundamental Biology and Roles in Cardiovascular Physiology. Annu Rev Physiol. 2016; DOI:10.1146/ annurev-physiol-021115-104929.

95. Zhang Y, Hu YW, Zheng L, Wang Q. Characteristics and Roles of Exosomes in Cardiovascular Disease. DNA Cell Biol. 2017; DOI:10.1089/ dna.2016.3496.

96. Foster BP, Balassa T, Benen TD, Dominovic M, Elmadjian GK, Florova V, Fransolet MD, Kestlerova A, Kmiecik G, Kostadinova IA, Kyvelidou C, Meggyes M, Mincheva MN, Moro L, Pastuschek J, Spoldi V, Wandernoth P, Weber M, Toth B, Markert UR. Extracellular vesicles in blood, milk and body fluids of the female and male urogenital tract and with special regard to reproduction. Crit Rev Clin Lab Sci. 2016; DOI:10.1080/104 08363.2016.1190682.

97. Knight M, Redman CWG, Linton EA, Sargent IL. Shedding of syncytiotrophoblast microvilli into the maternal circulation in pre-eclamptic pregnancies. BJOG An Int J Obstet Gynaecol. 1998; DOI:10.1111/j.1471-0528.1998.tb10178.x. 
98. Mincheva-Nilsson L, Baranov V. Placenta-Derived Exosomes and Syncytiotrophoblast Microparticles and their Role in Human Reproduction Immune Modulation for Pregnancy Success. Am J Reprod Immunol. 2014; DOI:10.1111/aji.12311.

99. Delorme-Axford E, Donker RB, Mouillet JF, Chu T, Bayer A, Ouyang Y, Wang T, Stolz DB, Sarkar SN, Morelli AE, Sadovsky Y, Coyne CB. Human placental trophoblasts confer viral resistance to recipient cells. Proc Natl Acad Sci U S A. 2013; DOI:10.1073/pnas.1304718110.

100. Reátegui E, Van Der Vos KE, Lai CP, Zeinali M, Atai NA, Aldikacti B, Floyd FP, Khankhel A, Thapar V, Hochberg FH, Sequist L V., Nahed B V., Carter B, Toner M, Balaj L, Ting D, Breakefield XO, Stott SL. Engineered nanointerfaces for microfluidic isolation and molecular profiling of tumor-specific extracellular vesicles. Nat Commun. 2018;9:1-11; DOI:10.1038/s41467-017-02261-1.

101. Ren Y, Yang J, Xie R, Gao L, Yang Y, Fan H, Qian K. Exosomal-like vesicles with immune-modulatory features are present in human plasma and can induce CD4+ T-cell apoptosis in vitro. Transfusion. 2011;51:100211; DOI:10.1111/j.1537-2995.2010.02909.x.

102. Wu Y, Deng W, Klinke DJ. Exosomes: Improved methods to characterize their morphology, RNA content, and surface protein biomarkers. Analyst. 2015;140:6631-42; D0I:10.1039/c5an00688k.

103. Lässer C, Eldh M, Lötvall J. Isolation and characterization of RNA-containing exosomes. J Vis Exp. 2012:1-6; DOI:10.3791/3037.

104. Woo HK, Sunkara V, Park J, Kim TH, Han JR, Kim CJ, Choi H Il, Kim YK, Cho YK. Exodisc for Rapid, Size-Selective, and Efficient Isolation and Analysis of Nanoscale Extracellular Vesicles from Biological Samples. ACS Nano. 2017;11:1360-70; DOI:10.1021/acsnano.6b06131.

105. Gao F, Jiao F, Xia C, Zhao Y, Ying W, Xie Y, Guan X, Tao M, Zhang Y, Qin W, Qian X. A novel strategy for facile serum exosome isolation based on specific interactions between phospholipid bilayers and TiO2. Chem Sci. 2019;10:1579-88; DOI:10.1039/c8sc04197k.

106. Escudier B, Dorval T, Chaput N, André F, Caby MP, Novault S, Flament C, Leboulaire C, Borg C, Amigorena S, Boccaccio C, Bonnerot C, Dhellin O, Movassagh M, Piperno S, Robert C, Serra V, Valente N, Le Pecq JB, Spatz A, Lantz O, Tursz T, Angevin E, Zitvogel L. Vaccination of metastatic melanoma patients with autologous dendritic cell (DC) derived-exosomes: Results of the first phase 1 clinical trial. J Transl Med. 2005;3; DOI:10.1186/1479-5876-3-10.

107. Heinemann ML, Ilmer M, Silva LP, Hawke DH, Recio A, Vorontsova MA Alt E, Vykoukal J. Benchtop isolation and characterization of functional exosomes by sequential filtration. J Chromatogr A. 2014;1371:125-35 DOI:10.1016/j.chroma.2014.10.026.

108. Böing AN, van der Pol E, Grootemaat AE, Coumans FAW, Sturk A, Nieuwland R. Single-step isolation of extracellular vesicles by size-exclusion chromatography. J Extracell Vesicles. 2014;3; DOI:10.3402/jev. v3.23430.

109. Kang K, Lee SS, Hyun K, Lee SJ, Kim JM. DNA-based highly tunable particle focuser. Nat Commun. 2013;4:1-8; DOI:10.1038/ncomms3567.

110. Liu C, Guo J, Tian F, Yang N, Yan F, Ding Y, Wei J, Hu G, Nie G, Sun J. Field-Free Isolation of Exosomes from Extracellular Vesicles by Microfluidic Viscoelastic Flows. ACS Nano. 2017;11:6968-76; DOI:10.1021/ acsnano.7b02277.

111. Sitar S, Kejžar A, Pahovnik D, Kogej K, Tušek-Žnidarič M, Lenassi M, Žagar E. Size Characterization and Quantification of Exosomes by Asymmetrical-Flow Field-Flow Fractionation. Anal Chem. 2015;87:9225-33, DOI:10.1021/acs.analchem.5b01636.

112. Zhang H, Freitas D, Kim HS, Fabijanic K, Li Z, Chen H, Mark MT, Molina H, Martin AB, Bojmar L, Fang J, Rampersaud S, Hoshino A, Matei I, Kenific CM, Nakajima M, Mutvei AP, Sansone P, Buehring W, Wang H, Jimenez JP, Cohen-Gould L, Paknejad N, Brendel M, Manova-Todorova K, Magalhães A, Ferreira JA, Osório H, Silva AM, Massey A, Cubillos-Ruiz JR, Galletti G, Giannakakou P, Cuervo AM, Blenis J, Schwartz R, Brady MS, Peinado H, Bromberg J, Matsui H, Reis CA, Lyden D. Identification of distinct nanoparticles and subsets of extracellular vesicles by asymmetric flow field-flow fractionation. Nat Cell Biol. 2018;20:332-43 DOI:10.1038/s41556-018-0040-4.

113. Kang D, Oh S, Ahn SM, Lee BH, Moon MH. Proteomic analysis of exosomes from human neural stem cells by flow field-flow fractionation and nanoflow liquid chromatography-tandem mass spectrometry. J Proteome Res. 2008;7:3475-80; DOI:10.1021/pr800225z.

114. Chen C, Skog J, Hsu CH, Lessard RT, Balaj L, Wurdinger T, Carter BS, Breakefield XO, Toner M, Irimia D. Microfluidic isolation and transcriptome analysis of serum microvesicles. Lab Chip. 2010;10:505-11; DOI:10.1039/b916199f.

115. Zhao Z, Yang Y, Zeng Y, He M. A microfluidic ExoSearch chip for multiplexed exosome detection towards blood-based ovarian cancer diagnosis. Lab Chip. 2016;16:489-96; DOI:10.1039/c5lc01117e.
116. Yoo CE, Kim G, Kim M, Park D, Kang HJ, Lee M, Huh N. A direct extraction method for microRNAs from exosomes captured by immunoaffinity beads. Anal Biochem. 2012;431:96-8; DOI:10.1016/j.ab.2012.09.008.

117. Cai S, Luo B, Jiang P, Zhou X, Lan F, Yi Q Wu Y. Immuno-modified superparamagnetic nanoparticles via host-guest interactions for high-purity capture and mild release of exosomes. Nanoscale. 2018;10:14280-9; DOI:10.1039/c8nr02871k.

118. Théry C, Amigorena S, Raposo G, Clayton A. Isolation and Characterization of Exosomes from Cell Culture Supernatants and $\mathrm{Bi}-$ ological Fluids. Curr Protoc Cell Biol. 2006;30:3.22.1-3.22.29; DOI:10.1002/0471143030.cb0322s30.

119. Johnstone RM, Adam M, Hammond JR, Orr L, Turbide C. Vesicle formation during reticulocyte maturation. Association of plasma membrane activities with released vesicles (exosomes). J Biol Chem. 1987;262:9412-20

120. Kim J, Tan Z, Lubman DM. Exosome enrichment of human serum using multiple cycles of centrifugation. Electrophoresis. 2015;36:2017-26; DOI:10.1002/elps.201500131

121. Vidal M, Mangeat P, Hoekstra D. Aggregation reroutes molecules from a recycling to a vesicle-mediated Secretion pathway during reticulocyte maturation. J Cell Sci. 1997;110:1867-77.

122. Albertsson P åke, Frick G. Partition of virus particles in a liquid two-phase system. BBA - Biochim Biophys Acta. 1960;37:230-7; DOI:10.1016/0006-3002(60)90228-6.

123. Rider MA, Hurwitz SN, Meckes DG. ExtraPEG: A polyethylene glycol-based method for enrichment of extracellular vesicles. Sci Rep. 2016;6:1-14; DOI:10.1038/srep23978.

124. Macías M, Rebmann V, Mateos B, Varo N, Perez-Gracia JL, Alegre E, González Á. Comparison of six commercial serum exosome isolation methods suitable for clinical laboratories. Effect in cytokine analysis. Clin Chem Lab Med. 2019;57; DOI:10.1515/cclm-2018-1297.

125. Davies RT, Kim J, Jang SC, Choi EJ, Gho YS, Park J. Microfluidic filtration system to isolate extracellular vesicles from blood. Lab Chip. 2012;12:5202-10; DOI:10.1039/c2lc41006k.

126. Lee K, Shao H, Weissleder R, Lee H. Acoustic purification of extracellular microvesicles. ACS Nano. 2015; 9:2321-7; DOI:10.1021/nn506538f

127. Wang Z, Wu HJ, Fine D, Schmulen J, Hu Y, Godin B, Zhang JXJ, Liu X. Ciliated micropillars for the microfluidic-based isolation of nanoscale lipid vesicles. Lab Chip. 2013;13:2879-82; DOI:10.1039/c3lc41343h.

128. Ibsen SD, Wright J, Lewis JM, Kim S, Ko SY, Ong J, Manouchehri S, Vyas A, Akers J, Chen CC, Carter BS, Esener SC, Heller MJ. Rapid Isolation and Detection of Exosomes and Associated Biomarkers from Plasma. ACS Nano. 2017;11:6641-51; DOI:10.1021/acsnano.7b00549.

129. Alvarez-Llamas G, De La Cuesta F, Barderas MEG, Darde V, Padial LR, Vivanco F. Recent advances in atherosclerosis-based proteomics: New biomarkers and a future perspective. Expert Rev Proteomics. 2008;5:679-91; DOI:10.1586/14789450.5.5.679.

130. Simpson RJ, Lim JWE, Moritz RL, Mathivanan S. Exosomes: Proteomic insights and diagnostic potential. Expert Rev Proteomics. 2009;6:26783; DOI:10.1586/epr.09.17.

131. Giusti I, Francesco M, Dolo V. Extracellular Vesicles in Glioblastoma: Role in Biological Processes and in Therapeutic Applications. Curr Cancer Drug Targets. 2016;17:221-35; DOI:10.2174/1568009616666160 813182959.

132. Zhou H, Pisitkun T, Aponte A, Yuen PST, Hoffert JD, Yasuda H, Hu X, Chawla L, Shen RF, Knepper MA, Star RA. Exosomal Fetuin-A identified by proteomics: A novel urinary biomarker for detecting acute kidney injury. Kidney Int. 2006;70:1847-57; DOI:10.1038/sj.ki.5001874.

133. Sandfeld-Paulsen B, Aggerholm-Pedersen N, Bæk R, Jakobsen KR, Meldgaard P, Folkersen BH, Rasmussen TR, Varming K, Jørgensen MM, Sorensen BS. Exosomal proteins as prognostic biomarkers in non-small cell lung cancer. Mol Oncol. 2016;10:1595; DOI:10.1016/j. molonc.2016.10.003.

134. Doyle L, Wang M. Overview of Extracellular Vesicles, Their Origin, Composition, Purpose, and Methods for Exosome Isolation and Analysis. Cells. 2019;8:727; DOI:10.3390/cells8070727.

135. Sonoda H, Yokota-Ikeda N, Oshikawa S, Kanno Y, Yoshinaga K, Uchida K, Ueda Y, Kimiya K, Uezono S, Ueda A, Ito K, Ikeda M. Decreased abundance of urinary exosomal aquaporin-1 in renal ischemia-reperfusion injury. Am J Physiol - Ren Physiol. 2009;297; DOI:10.1152/ ajprenal.00200.2009.

136. Bobrie A, Colombo M, Raposo G, Théry C. Exosome Secretion: Molecular Mechanisms and Roles in Immune Responses. Traffic. 2011;12:165968; DOI:10.1111/j.1600-0854.2011.01225.x.

137. Chaput N, Théry C. Exosomes: Immune properties and potential clinical implementations. Semin Immunopathol. 2011;33:419-40 DOI:10.1007/s00281-010-0233-9. 
138. Lai RC, Yeo RWY, Tan KH, Lim SK. Exosomes for drug delivery - A novel application for the mesenchymal stem cell. Biotechnol Adv. 2013;31:543-51; DOI:10.1016/j.biotechadv.2012.08.008.

139. Alvarez-Erviti L, Seow Y, Yin H, Betts C, Lakhal S, Wood MJA. Delivery of siRNA to the mouse brain by systemic injection of targeted exosomes. Nat Biotechnol. 2011;29:341-5; DOI:10.1038/nbt.1807.

140. Gatti S, Bruno S, Deregibus MC, Sordi A, Cantaluppi V, Tetta C, Camussi G. Microvesicles derived from human adult mesenchymal stem cells protect against ischaemia-reperfusion-induced acute and chronic kidney injury. Nephrol Dial Transplant. 2011;26:1474-83; D0I:10.1093/ ndt/gfr015.

141. Bruno S, Grange C, Collino F, Deregibus MC, Cantaluppi V, Biancone L, Tetta C, Camussi G. Microvesicles derived from mesenchymal stem cells enhance survival in a lethal model of acute kidney injury. PLoS One. 2012;7; DOI:10.1371/journal.pone.0033115.

142. Reis LA, Borges FT, Simões MJ, Borges AA, Sinigaglia-Coimbra R, Schor N. Bone Marrow-Derived Mesenchymal Stem Cells Repaired but Did Not Prevent Gentamicin-Induced Acute Kidney Injury through Paracrine Effects in Rats. PLoS One. 2012;7; DOI:10.1371/journal.pone.0044092.

143. Guo BB, Bellingham SA, Hill AF. Stimulating the release of exosomes increases the intercellular transfer of prions. J Biol Chem. 2016; DOI:10.1074/jbc.M115.684258.

144. Asai H, Ikezu S, Tsunoda S, Medalla M, Luebke J, Haydar T, Wolozin B, Butovsky O, Kügler S, Ikezu T. Depletion of microglia and inhibition of exosome synthesis halt tau propagation. Nat Neurosci. 2015 DOI:10.1038/nn.4132.

145. Rajendran L, Honsho M, Zahn TR, Keller P, Geiger KD, Verkade P, Simons K. Alzheimer's disease $\beta$-amyloid peptides are released in association with exosomes. Proc Natl Acad Sci U S A. 2006; DOI:10.1073/ pnas.0603838103.

146. Yuyama K, Sun H, Usuki S, Sakai S, Hanamatsu H, Mioka T, Kimura N, Okada M, Tahara H, Furukawa JI, Fujitani N, Shinohara Y, Igarashi Y. A potential function for neuronal exosomes: Sequestering intracerebral amyloid- $\beta$ peptide. FEBS Lett. 2015; DOI:10.1016/j.febslet.2014.11.027.

147. Stuendl A, Kunadt M, Kruse N, Bartels C, Moebius W, Danzer KM, Mollenhauer B, Schneider A. Induction of $\alpha$-synuclein aggregate formation by CSF exosomes from patients with Parkinson's disease and dementia with Lewy bodies. Brain. 2016; DOI:10.1093/brain/awv346.

148. Emmanouilidou E, Melachroinou K, Roumeliotis T, Garbis SD, Ntzouni M, Margaritis LH, Stefanis L, Vekrellis K. Cell-produced $\alpha$-synuclein is secreted in a calcium-dependent manner by exosomes and impacts neuronal survival. J Neurosci. 2010; D0I:10.1523/ JNEUROSCI.5699-09.2010.

149. Fraser KB, Rawlins AB, Clark RG, Alcalay RN, Standaert DG, Liu N, West AB. Ser(P)-1292 LRRK2 in urinary exosomes is elevated in idiopathic Parkinson's disease. Mov Disord. 2016; DOI:10.1002/mds.26686.

150. Benussi L, Ciani M, Tonoli E, Morbin M, Palamara L, Albani D, Fusco F, Forloni G, Glionna M, Baco M, Paterlini A, Fostinelli S, Santini B, Galbiati E, Gagni P, Cretich M, Binetti G, Tagliavini F, Prosperi D, Chiari M, Ghidoni R. Loss of exosomes in progranulin-associated frontotemporal dementia. Neurobiol Aging. 2016; DOI:10.1016/j. neurobiolaging.2016.01.001.

151. Buck AH, Coakley G, Simbari F, McSorley HJ, Quintana JF, Le Bihan T, Kumar S, Abreu-Goodger C, Lear M, Harcus Y, Ceroni A, Babayan SA Blaxter M, Ivens A, Maizels RM. Exosomes secreted by nematode parasites transfer small RNAs to mammalian cells and modulate innate immunity. Nat Commun. 2014:5:1-12; DOI:10.1038/ncomms6488.

152. Zhao Y, Sun X, Cao W, Ma J, Sun L, Qian H, Zhu W, Xu W. Exosomes Derived from Human Umbilical Cord Mesenchymal Stem Cells Relieve Acute Myocardial Ischemic Injury. Stem Cells Int. 2015;2015; DOI:10.1155/2015/761643.

153. Hu L, Wang J, Zhou X, Xiong Z, Zhao J, Yu R, Huang F, Zhang H, Chen L. Exosomes derived from human adipose mensenchymal stem cells accelerates cutaneous wound healing via optimizing the characteristics of fibroblasts. Sci Rep. 2016;6:1-11; DOI:10.1038/srep32993.

154. Li T, Yan Y, Wang B, Qian H, Zhang X, Shen L, Wang M, Zhou Y, Zhu W, $\mathrm{Li} \mathrm{W}, \mathrm{Xu}$ W. Exosomes derived from human umbilical cord mesenchymal stem cells alleviate liver fibrosis. Stem Cells Dev. 2013;22:845-54 DOI:10.1089/scd.2012.0395.

155. Fang S, Xu C, Zhang Y, Xue C, Yang C, Bi H, Qian X, Wu M, Ji K, Zhao Y, Wang Y, Liu H, Xing X. Umbilical Cord-Derived Mesenchymal Stem Cell-Derived Exosomal MicroRNAs Suppress Myofibroblast Differentiation by Inhibiting the Transforming Growth Factor-B/SMAD2 Pathway During Wound Healing. Stem Cells Transl Med. 2016;5:1425-39; DOI:10.5966/sctm.2015-0367.

156. Lv LL, Cao Y, Liu D, Xu M, Liu H, Tang RN, Ma KL, Liu BC. Isolation and quantification of MicroRNAs from urinary exosomes/microvesicles for biomarker discovery. Int J Biol Sci. 2013;9:1021-31; DOI:10.7150/ ijbs.6100. 